\title{
Increased susceptibility to audiogenic seizure resulting from injection of brain extract from acoustically primed mice
}

\author{
THOMAS M. CORWIN and A. L. STANFORD. JR. \\ School of Physics. Georgia Institute of Technologr: Atlanta. Georgia 30332
}

\begin{abstract}
Yice of the C57BL $6 \mathrm{~J}$ strain. which are normally nonsusceptible to audiogenic seizures. can be made susceptible by prior intense auditory stimulation. Since this "behavioral pattern" fits a general definition of learning, it was thought that effects of acoustical priming might be transferable in a manner similar to the transfer of learned behavior via injection of trained brain extract. Naive mice were injected with extract taken from the brains of primed mice. L sing littermate controls that consisted of both noninjected mice and mice injected with either saline or extract from nonprimed donors. it was concluded that injection of brain extract from acoustically primed mice increased the susceptibility to audiogenic seizure in $\mathrm{C} 57 \mathrm{BL} / 6 \mathrm{~J}$ mice.
\end{abstract}

Young mice of the normally nonsusceptible C57BL/6J strain can be made susceptible to audiogenic seizure by exposing them to prior intense auditory stimulation. This acoustical priming effect is age-specific, with maximum effectiveness occurring when priming is done at 16 days of age and testing at 21 days of age (Henry, 1967). Since the effects of priming bear some resemblance to learned behavior, it was decided to attempt a transfer experiment similar to those involving more conventional learned behavioral patterns (Ungar, 1967; Fjerdingstad et al. 1965: Babich et al, 1965).

It was hoped that injection of brain extract from primed mice would have the effect of priming and that the injected animals would have a high incidence of convulsion when tested on their 21st day of age without the normally necessary previous bell. This effect did not show up in our experiments. However, preliminary experiments did indicate that a second bell on the 24th day of age would produce a higher incidence of convulsion in mice that had been injected with brain extract from primed mice. Encouraged by these results. more detailed and better controlled experiments were performed. These experiments, which utilized both injected and noninjected littermate controls, will be reported here.

The hypotheses governing these experiments were: (1) Acoustical priming results in neural mechanisms which are in some manner similar to those initiated by a learning situation. (2) The structural changes within the brain which cause the animal to respond differently when the acoustical stimulus is presented at a later time are mediated by macromolecules (probably polypeptides). (3) The injection of these macromolecules into naive animals will alter their brain structure in a manner similar to the changes they normally would have caused in the donor animals' brain and thereby affect the recipient animals' response to acoustical stimuli.

\section{METHOD}

\section{Subjects and Apparatus}

The $\mathrm{S}$ mice were obtained from a colony that consisted of $\mathrm{C} 57 \mathrm{BL} / 5 \mathrm{~J}$ females obtained from Jackson Laboratories. Bar Harbor, Maine. and their offspring. Each pregnant female was housed in an individual cage, with tissue nesting material provided. Water and Purina Lab Chow were freely available. Overhead lights in the animal room were automatically turned on and off at 12-h intervals. Auditory stimulation was delivered in a glass chamber $(28.5 \mathrm{~cm}$ in diam and $26.5 \mathrm{~cm}$ deep) with a wooden top. Fastened to the underside of the top was a 114-dB (for entire spectrum; $105 \mathrm{~dB}$ for the octave centered at $8 \mathrm{kHz}$ ) electric doorbell $(6.5 \mathrm{~cm}$ in diam).

Procedure

At the age of 16 days. each donor litter was removed from its mother and the mice were individually taken into a separate room containing the sound chamber. They were then placed in the sound chamber. and the electric bell was rung for $30 \mathrm{sec}$. After each animal in the litter had been primed, the litter was returned to its mother. Donors were sacrificed by decapitation. Within $20 \mathrm{sec}$, their brains were removed and frozen in liquid nitrogen. These were stored in a freezer at $-20^{\circ} \mathrm{C}$ until 43 brains had been accumulated. The brains were then homogenized in a blender with $30 \mathrm{ml}$ of deionized distilled water and put in dialyzing bags. These were dialyzed against $600 \mathrm{ml}$ of deionized distilled water for 2 days. with continuous stirring for the first day. After lyophilization, the residue was redissolved in $5.75 \mathrm{ml}$ of deionized distilled water.

Experimental litters were removed from their mothers. and approximately one-half of each litter was injected intraperitoneally with $.25 \mathrm{cc}$ of primed brain extract (extract from approximately two donor mice). The remainder of the litter was either not injected or was injected with $.25 \mathrm{cc}$ of a control solution. After injection. the litters were returned to their mothers. At 21 days of age. the experimental mice were taken individually to the sound chamber and exposed to the bell in exactly the same way as the donor mice had been primed. This procedure was repeated at the age of 24 days.

The experiments involved several permutations of donor sacrifice time and recipient injection age. The experimental groups are represented in Table 1 . Those groups injected at 21 days of age were injected $2 \mathrm{~h}$ before the first test bell. The brain 
Table 1

\begin{tabular}{|c|c|c|c|c|c|}
\hline \multirow{2}{*}{$\begin{array}{l}\text { Experi- } \\
\text { mental } \\
\text { Group }\end{array}$} & \multirow{2}{*}{$\begin{array}{l}\text { Donor } \\
\text { Priming- } \\
\text { Sacrifice } \\
\text { Interval } \\
\text { (Days) }\end{array}$} & \multirow{2}{*}{$\begin{array}{l}\text { Injec- } \\
\text { tion } \\
\text { Age } \\
\text { (Days) }\end{array}$} & \multirow{2}{*}{$\begin{array}{c}\text { Recip- } \\
\text { ients } \\
\mathrm{N}\end{array}$} & \multicolumn{2}{|c|}{ Controls } \\
\hline & & & & $\begin{array}{l}\text { Control } \\
\text { Injectant }\end{array}$ & $\mathbf{N}$ \\
\hline 1 & 5 & 20 & 15 & None & 17 \\
\hline 2 & 5 & 21 & 6 & None & 9 \\
\hline 3 & 3 & 19 & 10 & None & 13 \\
\hline 4 & 1 & 17 & 7 & None & 9 \\
\hline 5 & 5 & 20 & 21 & $\begin{array}{l}\text { Nonprimed } \\
\text { Brain Extract }\end{array}$ & 21 \\
\hline 6 & 5 & 20 & 18 & $\begin{array}{l}\text { Physiological } \\
\text { Saline }\end{array}$ & 22 \\
\hline 7 & 5 & 18 & 19 & $\begin{array}{l}\text { Phyisiological } \\
\text { Saline }\end{array}$ & 19 \\
\hline 8 & 5 & 21 & 18 & $\begin{array}{l}\text { Physiological } \\
\text { Saline }\end{array}$ & 20 \\
\hline
\end{tabular}

extract from nonprimed mice was prepared in exactly the same manner as the brain extract from primed mice.

\section{RESULTS}

The incidence of response to the first test bell (bell at the age of 21 days) was low in both recipients and controls, with 12 out of 114 recipients exhibiting the wild running phase (Lehmann \& Busnel, 1963) and 5 out of 130 control animals exhibiting the wild running phase. The group showing the most effect was Group 7 , with 5 out of 19 recipients, as opposed to 1 out of 19 controls, exhibiting wild running. Group 7 was injected 3 days before the first test bell, whereas most of the other groups were injected either 1 day or $2 \mathrm{~h}$ before the first test.

At the second test bell (bell at age 24 days), however, the effect of the extract was much more apparent, as seen in Fig. 1. The most striking results were obtained using donors sacrificed 5 days after priming and recipients injected at age 20 days (Groups 1. 5. and 6). In these groups, the control animals were not injected. were injected with extract from nonprimed mice, and were injected with physiological saline, respectively. It is important to note that the results do not appear to be related to the control treatment, and, specifically, that the injections of nonprimed extract appears to be no different from no injections or physiological saline injections.

We do not wish to suggest that using donors sacrificed 5 days after priming and recipients injected at the age of 20 days represents the optimum procedure for demonstrating the effects of injection of brain extract from acoustically primed mice. The number of possible sacrifice-injection-testing permutations is large, and much more work is needed. It is possible, and we think probable, that a more appropriate procedure will demonstrate a clear effect on the first test bell.

Group 4 consisted of 16 mice from two litters of very small mice. Of these, 13 had fatal convulsions on the second test at 24 days of age. A high incidence of convulsion was noted in some of the other litters consisting of small mice. To avoid this effect, mice were weighed at 20 days of age and only those litters averaging $8 \mathrm{~g}$ or more per mouse were used in Group 5 . Mice were weighed at 18 days of age, and only those averaging over $7 \mathrm{~g}$ per mouse were used in Groups 6, 7, and 8 .

Group 2 had one fatal convulsion among the six recipient mice and two fatal convulsions among the nine littermate controls. This group is not shown in Fig. 1.

\section{DISCUSSION}

Experimental Groups 5 and 6 are procedurally the same, except that Group 5 controls were injected with brain extract from nonprimed mice and Group 6 controls were injected with physiological saline. If we assume that these two injections are not different from one another with respect to their ability to affect audiogenic seizure susceptibility, we may combine these two groups, as shown in Fig. 2. Additionally, if we assume that intraperitoneal injection in general does not affect audiogenic seizure susceptibility, then we may combine Groups 1, 5, and 6. This is also shown in Fig. 2.

Group 5 is perhaps the critical group in these experiments, as this group indicates that brain extract per se is not responsible for the increased susceptibility to audiogenic seizure seen in the other experimental groups.

We feel that the reported results show that injection of brain extract from acoustically primed mice can increase the susceptibility of $\mathrm{C} 57 \mathrm{BL} / 6 \mathrm{~J}$ mice to audiogenic seizure. The preliminary experiments and those experiments reported in this paper represent data

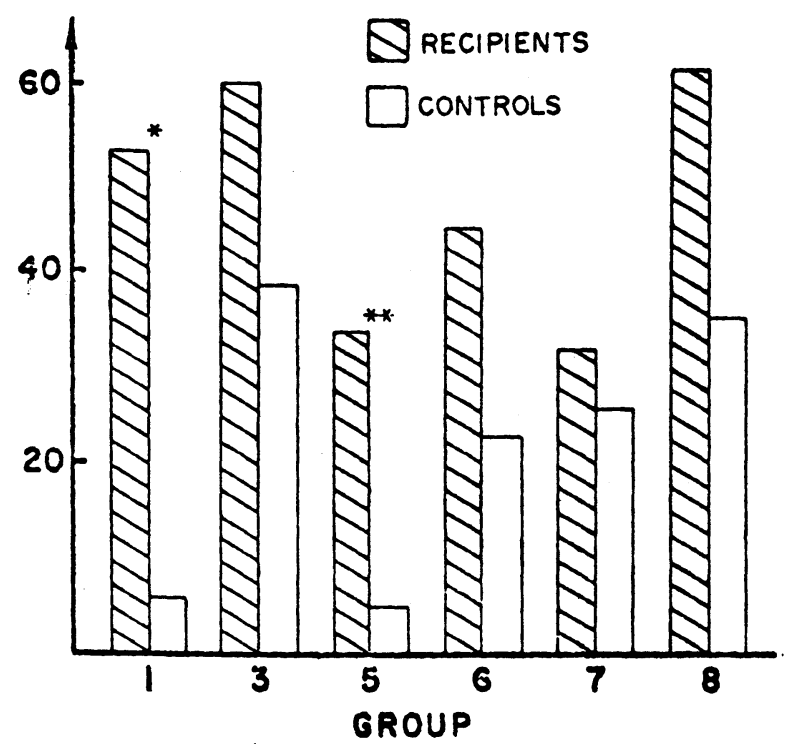

Fig. 1. Percentage of mice exhibiting tonic or fatal convulsions upon exposure to bell at 24 days of age. ${ }^{*} p=.0041$ using the exact method. ${ }^{* *} p=.0225$ using the exact method. 
from 274 mice. These 274 mice represent the entirety of our experiments, not just groups that were selected because they gave positive results, with groups giving no results being discarded. Of these 274 mice, 132 were injected with extract from primed mice and 142 were control mice. The incidence of tonic convulsion or greater among the 132 recipient animals was $47 \%$, whereas it was $25.3 \%$ among the 142 control animals. These results are shown in Fig. 2. A chi-square test indicates a level of significance of $p<.001$.

We also feel that the reported results give reasonable support to Hypothesis 1 , and at the very least indicate that the effects of priming are mediated by CNS mechanisms rather than by structural damage to the

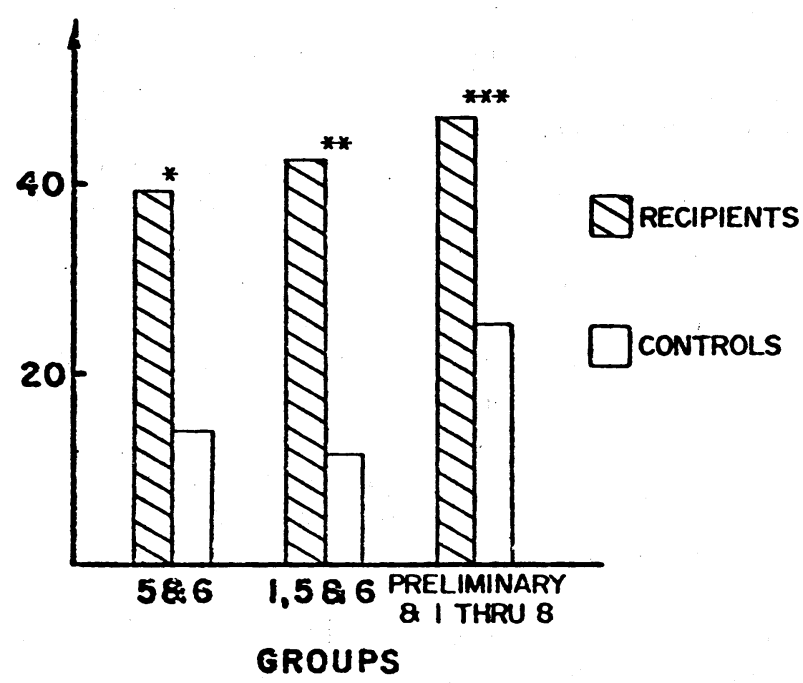

Fig. 2. Percentage of mice exhibiting tonic or fatal convulsions upon exposure to bell at 24 days of age. ${ }^{*} .02<p<.025$ using chi square with Yates correction. ${ }^{* *} p<.001$ using chi square with Yates correction. ${ }^{* * *} p<.001$ using chi square. inner ear. Henry (1.970) reports that amnesic agents such as hypothermia, ECS, and inhibitors of brain protein synthesis do not affect the priming results. The positive results of the transfer experiments reported here suggest that the effect of amnesic agents on acoustical priming should be studied in more detail. ${ }^{1}$

\section{REFERENCES}

Babich, F. R., Jacobson, A. L., Bubash, S., \& Jacobson, A. Transfer of a response to naive rats by injection of RNA from trained rats. Science, 1965, 149, 656-657.

Fjerdingstad, E. J., Nissen, T., \& Roigaard-Petersen, H. H. Effect of RNA extracted from the brains of trained animals on learning in rats. Scandinavian Journal of Psychology, 1965, 6, 1-6.

Henry, K. R. Audiogenic seizure susceptibility induced in C57BL/6J mice by prior auditory exposure. Science, 1967, $158,938-940$.

Henry, K. R., \& Bowman, R. E. Acoustical priming of audiogenic seizures in mice. In B. L. Welch and A. S. Welch (Eds.), Physiological effects of noise. New York: Plenum Press, 1970.

Lehmann, A., \& Busnel, R. G. A study of the audiogenic seizure. In R. G. Busnel (Ed.), Acoustic behavior of animals. New York: Elsevier, 1963.

Ungar, G. Chemical transfer of acquired information. Excerpta Medica, ICS, 1967, 129, 169-175.

\section{NOTE}

1. At the 137th meeting of the American Association for the Advancement of Science, E. J. Fjerdingstad reported unpublished results which indicated the possibility of transfer of the effects of acoustical priming.

\section{(Received for publication December 18, 1972;} revision received March 30, 1973; accepted July 16, 1973.) 